Article

\title{
Multi-Level Policy Dialogues, Processes, and Actions: Challenges and Opportunities for National REDD+ Safeguards Measurement, Reporting, and Verification (MRV)
}

\author{
Pamela Jagger 1,2,*, Maria Brockhaus ${ }^{2}$, Amy E. Duchelle ${ }^{3}$, Maria Fernanda Gebara ${ }^{4}$, \\ Kathleen Lawlor ${ }^{1}$, Ida Aju Pradnja Resosudarmo ${ }^{2}$ and William D. Sunderlin ${ }^{2}$ \\ 1 University of North Carolina at Chapel Hill, CB\#3435 Abernethy Hall, \\ Chapel Hill, NC 27599-3435, USA; E-Mail: klawlor@email.unc.edu \\ 2 Center for International Forestry Research, Bogor, Jalan CIFOR, Situ Gede, Sindang Barang, \\ P.O. Box 0113 BOCBC, Bogor 16000, Indonesia; E-Mails: m.brockhaus@cgiar.org (M.B.); \\ d.resosudarmo@cgiar.org (I.A.P.R.); w.sunderlin@cgiar.org (W.D.S.) \\ 3 Center for International Forestry Research, Rua do Russel 450, Sala 601, CEP: 2210-010, \\ Rio de Janeiro, RJ, Brazil; E-Mail: a.duchelle@cgiar.org \\ 4 Federal Rural University of Rio de Janeiro. Av. Pres.Vargas, 417 oviatoandar, CEP: 20071-003, \\ Rio de Janeiro, RJ, Brazil; E-Mail: mfgebara@gmail.com \\ * Author to whom correspondence should be addressed; E-Mail: pjagger@unc.edu; \\ Tel.: +1-919-962-6848; Fax: +1-919-962-5824.
}

Received: 20 May 2014; in revised form: 16 August 2014 / Accepted: 1 September 2014 / Published: 15 September 2014

\begin{abstract}
REDD+ social safeguards have gained increasing attention in numerous forums. This paper reviews the evolution of multi-level policy dialogues, processes, and actions related to REDD+ social safeguards (e.g., Cancun Safeguards 1-5) among policy makers, civil society organizations, and within the media in Brazil, Indonesia and Tanzania, three countries with well advanced REDD+ programs. We find that progress on core aspects of social safeguards is uneven across the three countries. Brazil is by far the most advanced having drafted a REDD+ social safeguards policy. Both Brazil and Indonesia have benefited from progress made by strong sub-national entities in the operationalization of REDD+ safeguards including free prior and informed consent (FPIC), participation, and benefit sharing. Tanzania has weakly articulated how social safeguards will be operationalized and has a more top-down approach. We conclude that in all three countries, measuring, reporting and verifying progress on social safeguards is likely to be a complex issue.
\end{abstract}


Stakeholders with vested interests in REDD+ social safeguards operate in polycentric rather than nested systems, suggesting that aggregation of information from local to national-scale will be a challenge. However, polycentric systems are also likely to support more transparent and comprehensive safeguards systems. Clear direction from the international community and financing for REDD+ safeguard MRV is essential if REDD+ social safeguards are to be meaningfully integrated into forest-based climate mitigation strategies.

Keywords: benefit sharing; governance; FPIC; tenure; participation; policy; polycentric

\section{Introduction}

In recent years, initiatives to reduce emissions from deforestation and degradation and enhance forest carbon stocks in developing countries (REDD+) have played a prominent role in international forest conservation finance, implementation, and policy discourse. Over 200 REDD + projects in approximately 40 countries exist around the globe [1]; government-led subnational REDD+ programs have emerged in multiple countries, national programs are under development in all regions of the world, and negotiations regarding REDD + have progressed much faster than in other areas of international climate talks. REDD+ was originally conceived as a market-based carbon-offsetting scheme, where emitters in developed countries (e.g., companies with emissions caps or individuals with voluntary motivations) pay entities in developing countries to reduce deforestation below a projected counterfactual scenario in order to offset the carbon emissions in developed countries. As incentive-based, results-driven environmental policy, many believe REDD+ holds promise to bring about transformational change and deliver "triple wins" for climate, forests, and poverty reduction [2]. To others the potential for governments, companies, and conservation organizations to make forest conservation a profitable endeavour via carbon markets has sparked concerns that REDD+ would harm local populations by ignoring customary tenure rights and restricting land use and access to forests without sufficient compensation or alternatives [3]. In response to such concerns, the governance and social dimensions of REDD+ have received increasing attention amongst stakeholders as programs and projects develop, with many adopting policies designed to "safeguard" vulnerable populations from harm. Some have gone a step further to insist that REDD+ must also benefit local populations [4].

There has been tremendous evolution in policy dialogue, process and action on REDD+ social safeguards over the past five years. Safeguards have gone from being a nascent aspect of REDD+ discourse at the Bali Conference of the Parties (COP) in 2008, to an important contemporary agenda item for negotiators and key stakeholders at annual COPs, Subsidiary Body for Scientific and Technological Advice (SBSTA) meetings, and in various national, international and local forums. Countries are contemplating how to build national Safeguard Information Systems (SIS), which will make them eligible for results-based payments based on reporting on the delivery of social and environmental co-benefits and avoidance of harm. In the lead up to COP 20 in Lima, Peru, there is anticipation of international consensus on REDD+ social safeguards and setting of expectations for measurement, reporting and verification (MRV) of safeguards to the United Nations Framework Convention on Climate Change (UNFCCC). 
Our aim is to analyse the institutionalization of REDD+ social safeguards through the development of international, national, sub-national policies, processes, and actions directly related to the implementation and monitoring and evaluation of REDD + . The evolution of REDD + social safeguard institutions has three notable features. First, REDD+ social safeguards establish norms (vs. rules) for governance, social, and environmental (e.g., biodiversity and environmental services) outcomes. As norms they are agreed upon by the majority of key stakeholders, but actors who do not adhere to them are not formally sanctioned. This makes social safeguards fundamentally different than performance-based indicators including leakage and permanence that determine payments for carbon. Second, the UNFCCC safeguards articulated in Cancun and parallel processes related to monitoring and evaluation of REDD+ social impacts reflect input from several stakeholders and communities of interest operating at multiple levels. The diversity of actors and levels of action represents a highly complex system of interactions and incentives, suggesting high costs of coordination. Third, actors operating in different contexts and roles exert varying levels of power and influence, and can have either complementary or competing agendas. The possibility of competing interests means that collective action is required to move towards a mutually agreeable and timely plan for social safeguards.

Polycentric institutional systems, defined as systems with multiple centers, have several characteristics that are suitable for solving problems surrounding the provision of public goods [5]. This is true particularly when public goods arise from efforts to control indirect consequences, externalities or spillover effects, the good or service in question is not easily packaged, or the public good seeks to maintain some preferred state of community affairs (i.e., limit adverse effects and encourage positive ones). However, polycentric systems may fail to recognize the diversity of interests within given boundaries, working more effectively when all parties benefit from cooperation, and faltering when conflict arises [6]. When analyzing multi-level institutional structures, polycentric systems are often compared with institutional systems that are nested in organizational structure and lend themselves nicely to the transfer of knowledge, aggregation of information, clearly identifiable hierarchy, and consistent objectives across scales. The structure of multi-level institutions has implications for how they evolve at local, sub-national and national scales, the way they are debated, and implications for discourse surrounding their evolution for example with regards to legitimacy [7], which in turn affects how safeguards are operationalized within and across levels.

Our research question is: what do multi-level policy dialogues, processes and actions on core aspects of REDD+ social safeguards mean for the development of national-level safeguard systems? We hypothesize that countries with polycentric systems, meaning those with multiple independent yet overlapping centers of decision-making, are better positioned to develop national safeguard systems. We draw on evidence from CIFOR's Global Comparative Study on REDD+ (GCS-REDD+) to analyse the evolution and current state of social safeguards for REDD+ in three countries: Brazil, Indonesia and Tanzania. These countries have been leaders in their respective regions in both developing national REDD + architecture and piloting REDD + projects and programs. While their safeguard policies and actions respond in part to the same set of international guidance and incentives, their responses and contexts vary in important ways.

Our approach is to first chronicle international developments in the UNFCCC COPs, in subordinate forums including the Subsidiary Body for Scientific and Technical Advice (SBSTA), which focuses on 
the technical issues of implementing REDD+ policy, and on the development and implementation of various internationally-recognized standards for ensuring adherence to REDD+ social safeguards. We then draw on data from the GCS-REDD + to examine the evolution of national, sub-national, civil society, and media policy dialogues, processes and actions related to key aspects of the REDD+ social safeguards articulated in the Cancun Agreement. We undertake a comparative analysis drawing on a series of CIFOR Working Papers on the context of REDD+ [8-10], media analyses [11-13], and qualitative data collected on actions related to social safeguards in subnational REDD+ sites. Given that REDD+ safeguards are evolving in multiple policy arenas and markets, and at varying scales of governance, we comment on the implications of these overlapping dialogues, processes and actions for the further development of REDD+ social safeguards in general, and specifically on the challenges and opportunities for measuring, reporting and verifying outcomes.

\section{The Evolution of Institutions to Safeguard and Promote Human Welfare in REDD+}

Forest carbon projects have existed since the mid-1990s with the majority situated in Latin America. The primary focus of these projects was reducing deforestation and estimate net impacts on greenhouse gas emissions. A number of early forest carbon projects monitored biodiversity, but only limited attention was given to assessing livelihood impacts [14]. In 2007, at the 13th UNFCCC COP, the parties adopted the "Bali Action Plan", which paved the way for REDD+. The focus of early dialogues on REDD + revolved around MRV of reduced deforestation and degradation. The Bali Action Plan [15] included only minimal language regarding the needs of local communities, which stood to be significantly affected through changes in access to forests. Following adoption of the Bali Action Plan, advocates pressed the Parties to include language recognizing indigenous peoples' rights and safeguarding the welfare of local communities [16]. These calls were initially met with resistance by those worried that REDD+ would become overburdened with social objectives, distracting from its purpose as a tool for protecting forests for the purpose of mitigating climate change (e.g., [17]). However, by 2010, as evidenced by the language of the Cancun Agreement reached at the UNFCCC COP 16 [18], Parties are called upon to promote, support and report on the implementation of seven social and environmental safeguards for REDD+:

1. Complement national forest programs and international conventions and agreements

2. Maintain transparent governance

3. Respect the knowledge and rights of indigenous peoples and local communities

4. Obtain effective participation of indigenous peoples and local communities in the design and implementation of REDD+

5. Avoid the conversion of natural forests and ensure that activities conserve forests, biodiversity, ecosystem services, and enhance other social benefits

6. Address risks of reversals (i.e., seek to achieve permanence)

7. Reduce leakage 
Since COP 16, Parties' support for both safeguards and non-carbon "co-benefits" appears to have strengthened. At COP 17 in Durban, South Africa, parties committed to developing guidance on how countries could address and report on safeguards (known as "Safeguard Information Systems" (SIS) [19]. To advance and guide negotiations at Doha's COP 18, Parties met in Bangkok in September 2012 and forged an informal draft REDD+ text that puts forward multiple options for each aspect of the REDD+ architecture [20]. Included in these options is the suggestion that carbon and non-carbon benefits are inextricably linked, as well as a request that results-based payments be contingent on the provision of both carbon and non-carbon benefits. Non-carbon benefits of REDD+ are the suite of ecosystem services provided by forests (in addition to carbon storage) as well as social and development benefits. In the work plan agreed to by the parties at COP 18 in Doha, investigating options for incentivizing non-carbon benefits is given a prominent place on the agenda [21]. The Warsaw Agreement, established at COP 19, requires that countries establish SIS to be eligible for results-based payments [22].

Simultaneously with the Parties' adoption of the Cancun Agreement language, several voluntary certification standards for assessing these projects' social and environmental impacts have emerged. The most prominent of these is the Climate, Community and Biodiversity (CCB) Standard, initiated in 2003, which requires that projects demonstrate net positive impacts on local communities and biodiversity. The CCB standard has been adopted by an estimated $64 \%$ of all forest carbon projects [23] and nearly $60 \%$ of forest carbon credits sold on the voluntary market in 2010 came from CCB-certified projects [24]. Widespread and voluntary uptake of the CCB Standard is an example of what Cashore refers to as "non-state market-driven governance" [25], reflecting the ideas and interests of actors on both the demand-side (investors, consumers) and supply-side (project proponents) of REDD+.

There are also initiatives to promote social safeguards at higher, jurisdictional levels. The REDD+ Social and Environmental Standards (REDD+ SES) initiative, led by the Climate, Community and Biodiversity Alliance (CCBA) and CARE International, brings together civil society, the private sector, and government agencies to build jurisdiction-specific indicators to track the compliance of government-led REDD+ programmes with the initiative's seven principles and 28 supporting criteria. These principles include commitments to enhance the wellbeing of local communities and contribute to good governance [26]. REDD+ SES currently supports the implementation of SIS by several subnational jurisdictions in Brazil, Indonesia, Mexico and Peru, and by national governments in Ecuador, Nepal, Tanzania, Guatemala, and Liberia.

Multilateral and bilateral donors have safeguard policies of their own. The World Bank Group's (WBG) Forest Carbon Partnership Facility (FCPF), which works with countries to build their institutional capacity for the design and implementation of REDD+, is now applying the institution's environmental and social risk management framework and Safeguard Policies to REDD+ [27]. Meanwhile, the UN REDD Programme has developed social and environmental principles and criteria that are congruent with the Cancun Agreement's safeguards [28]. Bilateral donors, such as the United States Agency for International Development (USAID), the Norwegian Agency for development (NORAD), and Australian Aid, are crafting safeguard policies for their REDD+ programs. The state of California, which recently adopted a cap-and-trade system, will allow a small percentage of permissible offsets to come from international forestry programs and will likely adopt their own safeguard policies [29]. 
Considerable work remains to be done to provide guidance to countries on how to measure and report on compliance with safeguards. Progress on developing such guidance has been slower than what the Parties committed themselves to at Cancun. The agreement and guidance being forged at the UNFCCC on SIS attempts to strike a balance between prescriptive rules, national sovereignty and transaction costs. On the one hand, it aims to provide REDD+ countries with detailed guidance, so they can identify negative impacts and allow stakeholders to judge how well safeguards are being implemented. On the other hand, it acknowledges that countries vary in their capacity to implement and report on safeguards, and that systems are already in place, which should be built upon rather than duplicated [19]. Many stakeholders are waiting for SBSTA to further clarify the definition and monitoring and reporting requirements of REDD+ safeguards. At the same time, other international bodies, including the Convention on Biological Diversity (CBD), the United Nations Declaration on the Rights of Indigenous Peoples (UN DRIP) and the Universal Declaration on Human Rights, are observing whether their social and environmental safeguard policies are harmonised with those of REDD+ [30].

\section{Data and Methods}

We analyse data collected by the Center for International Forestry Research's Global Comparative Study on REDD+ (GCS-REDD+) to characterize national and subnational-level dialogues, processes and actions with REDD+ social safeguards. GCS-REDD+ is a multi-dimensional study with five components: (1) national REDD+ strategies and policies; (2) design, implementation, and socio-economic impacts of sub-national REDD+ initiatives; (3) MRV of forest carbon emissions reductions; (4) multi-level governance and carbon in the landscape, and mitigation-adaptation synergies; and (5) knowledge sharing on REDD+ implementation and outcomes with policy makers and other key stakeholders [31]. The research program has a nested research design with data collection taking place at regional, national, sub-national, project, village and household scales. GCS-REDD+ research is ongoing in 13 countries and involves numerous partners.

Our analysis focuses on social safeguards — specifically safeguards 1-5, excluding permanence and leakage, which fall within the domain of carbon MRV. We use a qualitative comparative research design in our analysis, which leverages data from three sources: (1) synthetic literature reviews and key informant interviews on national and sub-national REDD + policy dialogues, processes and actions; (2) national-level media discourse on the topic of REDD+; and (3) interviews with proponents of subnational REDD+ initiatives on the role of social safeguards in their design and implementation. The first two datasets are secondary and part of the GCS-REDD+ component focused on the national REDD+ strategies and policies. The third is a primary dataset collected as part of the GCS-REDD+ component on subnational REDD + initiatives. To maximize our understanding of the policy process in multiple settings, we use data from three countries: Brazil, Indonesia and Tanzania. These countries are at the forefront of REDD+ development in their respective regions representing cases where we would expect the most advancement on social safeguards.

Our first data source is published GCS-REDD+ country-level studies that provide comprehensive analyses of national and sub-national policy dialogues, processes and actions on key aspects of REDD + . We reviewed these studies with the aim of understanding how REDD + social safeguards are 
being addressed through REDD+ readiness processes, and national and sub-national policy dialogues, processes and actions. Country-level studies were conducted between 2008 and 2012. They involved critical literature reviews of both peer reviewed and grey literature, as well as interviews with key informants [8-10].

Our second data source is published GCS-REDD+ media analyses. Boykoff argues that the media play an influential role in shaping policy discourses by educating stakeholders and framing issues in ways that build consensus for a particular issue [32]. To understand how national and international REDD+ policy dialogues influence the ideas and information held by citizens in these countries, we reviewed media analyses to assess the degree to which REDD+ policy formulation and implementation appear in national newspapers between 2005 and 2012 [11-13]. In these media analyses, print articles of major national newspapers were selected based on a key word search, and analysed regarding the framing of the articles, and the stances or position statements of actors advocating or avoiding these frames. The analysis in each country followed a pre-defined coding system [33]. Analysis of print media was supplemented with journalist interviews. Three researchers independently reviewed and synthesized country-level and media reports for evidence of policy attention to the core components of the REDD+ safeguards outlined above.

Our third data source is interviews with proponents of subnational REDD + initiatives. To understand how aspects of social safeguards are being operationalized at the project-level, we interviewed proponents to understand their motivations and experiences with safeguarding the welfare of local communities. The survey included both qualitative and quantitative questions on FPIC and local participation in the design and implementation of the REDD + initiative, and was conducted through in-person or Skype-based interviews that took about one hour. Data were collected from 16 subnational initiatives in Brazil (4), Indonesia (6) and Tanzania (6). The GCS-REDD+ team interviewed proponents with the aim of understanding the extent to which their projects or programs fulfil the following targets: (i) respect for the rights of indigenous people and local communities (Safeguard \#3); and (ii) facilitation of the full and effective participation of local stakeholders Safeguard \#4). These data were collected in 2011 at the start of the REDD+ implementation phase. We do not identify initiatives by name to protect the confidentiality of data provided by proponents.

Our analysis is not intended to be causal, but rather descriptive and comparative in nature. We seek to highlight the similarities and differences in policy dialogues, processes, and action in three countries considered to be international leaders in REDD+, and regional leaders in the development of national policy action on REDD+. Acknowledging the changing policy environment, our analysis portrays the development of REDD+ between 2008 and 2012. Because REDD + policy and process is evolving rapidly, the results of the country profiles, media analyses and interviews with proponents presented here provide only a snapshot of the current state of REDD+ safeguards in three countries. 


\section{Results}

\subsection{Jurisdictional (National and Sub-National) Dialogue, Processes, and Action Surrounding REDD+} Social Safeguards

All three countries in our study are signatories to most international agreements related to the forestry sector including the UNFCCC and the CBD (Safeguard \#1), suggesting REDD+ policy should not contradict those agreements. Several conventions have statements on social impacts; for example, the CBD has its own statements on social safeguards. Tanzania is the only country that conducts cross-sectoral discussions, including reconciling specific provisions related to forests in legally-binding and non-binding instruments related to various international agreements (Table 1). Notably, Brazil and Tanzania are not signatories to Voluntary Partnership Agreements (VPA) of the Forest Law Enforcement, Governance and Trade (FLEGT) a European Union led initiative to curb the trade of illegally harvested timber. VPAs are a policy mechanism that is relatively well-aligned with the overall objectives of REDD+.

At the national level, the potential for strengthening existing forestry institutions was a major theme of policy dialogues surrounding complementarities with existing national forest programs (Safeguard \#1) in all three countries. In Brazil and Indonesia, competing claims on forests that extend beyond REDD+ were also discussed. Oil palm plantations (Indonesia) and livestock (Brazil) involve large-scale deforestation, putting them in direct conflict with fulfilling the objectives of REDD+. Policy actors representing large-scale agriculture and timber harvesting have an active voice in REDD+ debates in Brazil and Indonesia, and actors engaged in biofuel development participate in national REDD+ policy discussions in all three countries.

Deficiencies of decentralized forest governance (e.g., lack of funding, weak capacity for implementing programs, corruption in local government, and weak enforcement of forestry laws at the local level) was identified as a major issue in all three countries and relates to maintaining transparent governance (Safeguard \#2). However, policy makers expressed hope that REDD+ might provide the resources to build capacity and address challenges central to effective forest governance at both national and sub-national scales. 
Table 1. Policy dialogues, processes and actions.

\begin{tabular}{|c|c|c|c|c|c|}
\hline & $\begin{array}{l}\text { Safeguard 1: } \\
\text { Synergy with National } \\
\text { Policies and International } \\
\text { Conventions }\end{array}$ & $\begin{array}{l}\text { Safeguard 2: } \\
\text { Transparent Governance }\end{array}$ & $\begin{array}{l}\text { Safeguard 3: } \\
\text { FPIC and Land Tenure }\end{array}$ & $\begin{array}{l}\text { Safeguard 4: } \\
\text { Participation }\end{array}$ & $\begin{array}{l}\text { Safeguard \#5: } \\
\text { Enhanced Social } \\
\text { Benefits (Benefit } \\
\text { Sharing) } \\
\end{array}$ \\
\hline Brazil & $\begin{array}{l}\text { Policy actors representing } \\
\text { large-scale industries with } \\
\text { competing claims to forests } \\
\text { have a voice in REDD+ (e.g., } \\
\text { agriculture, mining, biofuels) }\end{array}$ & $\begin{array}{l}\text { Competing interest of federal and } \\
\text { state governments with notable } \\
\text { REDD+ advancements and both } \\
\text { levels but challenges for } \\
\text { harmonization }\end{array}$ & $\begin{array}{l}\text { Civil society very vocal on FPIC } \\
\text { Land tenure highly contested despite } \\
\text { positive history of devolving } \\
\text { land rights to communities } \\
\text { and smallholders } \\
\text { Legal framework in place to give } \\
\text { recognition to indigenous lands }\end{array}$ & $\begin{array}{l}\text { Coordination of the Indigenous Organizations of the } \\
\text { Brazilian Amazon (COIAB) has a permanent seat on } \\
\text { the executive committee of the Amazon Fund } \\
\text { CSOs developed process to create social and } \\
\text { environmental principles and criteria for } \\
\text { REDD+ programs } \\
\text { Acre and Mato Grosso have structured forums to } \\
\text { encourage participation of key stakeholders } \\
\text { (but participation by indigenous people is weak) } \\
\text { Media gave considerable attention to participation } \\
\text { in REDD+ design, notably the role of indigenous } \\
\text { people in forest conservation }\end{array}$ & $\begin{array}{l}\text { No official proposal } \\
\text { for benefit sharing; } \\
\text { No clear statement } \\
\text { on what share of } \\
\text { compensation } \\
\text { mechanisms will be } \\
\text { related to social } \\
\text { aspects of REDD+ } \\
\text { Greater focus on } \\
\text { equity } v s \text {. sharing of } \\
\text { revenues/benefits at } \\
\text { local level }\end{array}$ \\
\hline
\end{tabular}


Table 1. Cont.

\begin{tabular}{|c|c|c|c|c|c|}
\hline & $\begin{array}{l}\text { Safeguard 1: } \\
\text { Synergy with National Policies } \\
\text { and International Conventions }\end{array}$ & $\begin{array}{l}\text { Safeguard 2: } \\
\text { Transparent } \\
\text { Governance }\end{array}$ & $\begin{array}{l}\text { Safeguard 3: } \\
\text { FPIC and Land Tenure }\end{array}$ & $\begin{array}{l}\text { Safeguard 4: } \\
\text { Participation }\end{array}$ & $\begin{array}{l}\text { Safeguard \#5: } \\
\text { Enhanced Social Benefits } \\
\text { (Benefit Sharing) } \\
\end{array}$ \\
\hline Indonesia & $\begin{array}{l}\text { Concern about other forest sector } \\
\text { policies contradicting REDD+ } \\
\text { Policy actors representing } \\
\text { large-scale industries with } \\
\text { competing claims to forests } \\
\text { have a voice in REDD }+ \\
\text { (e.g., agriculture, mining, biofuels) }\end{array}$ & $\begin{array}{l}\text { Competing } \\
\text { interest of } \\
\text { federal and state } \\
\text { governments }\end{array}$ & $\begin{array}{l}\text { UN-REDD and National Forestry Council } \\
\text { have developed FPIC materials and } \\
\text { guidelines; } \\
\text { National REDD+ Strategy has } \\
\text { discussion of FPIC } \\
\text { CSOs have focused on FPIC promoting } \\
\text { involvement of customary and local } \\
\text { communities in all aspects of REDD+ design } \\
\text { and implementation } \\
\text { National government has initiated major } \\
\text { tenure reforms through the One Map initiative } \\
\text { and Constitutional Court decision } 35 \text { on } \\
\text { indigenous ownership rights } \\
\text { CSOs let by AMAN have lobbied strongly for } \\
\text { recognition of indigenous ownership rights in } \\
\text { follow-up to the Constitutional decisions but } \\
\text { have failed }\end{array}$ & $\begin{array}{l}\text { Environmental Impact Assessments } \\
\text { (AMDAL) as an important instrument for } \\
\text { assessing community participation and } \\
\text { involvement; } \\
\text { Community participation required in } \\
\text { drafting of legislation (but largely } \\
\text { normative vs. operational); } \\
\text { Community participation is one of } 5 \text { pillars } \\
\text { of National REDD+ Architecture, but no } \\
\text { penalties for failing to comply } \\
\text { Major focus of CSOs, including concern } \\
\text { about lack of operational rules for } \\
\text { institutionalizing participation } \\
\text { Media focused on participation by regional } \\
\text { governments, but not on local participation }\end{array}$ & $\begin{array}{l}\text { UN-REDD led process on } \\
\text { benefit sharing system } \\
\text { Government regulation on } \\
\text { benefit sharing between } \\
\text { government, communities } \\
\text { and project developers } \\
\text { Concern that corruption will } \\
\text { threaten equitable benefit } \\
\text { sharing }\end{array}$ \\
\hline
\end{tabular}


Table 1. Cont

\begin{tabular}{|c|c|c|c|c|c|}
\hline & $\begin{array}{l}\text { Safeguard 1: } \\
\text { Synergy with National } \\
\text { Policies and International } \\
\text { Conventions }\end{array}$ & $\begin{array}{l}\text { Safeguard 2: } \\
\text { Transparent } \\
\text { Governance }\end{array}$ & $\begin{array}{l}\text { Safeguard 3: } \\
\text { FPIC and Land Tenure }\end{array}$ & $\begin{array}{l}\text { Safeguard 4: } \\
\text { Participation }\end{array}$ & $\begin{array}{l}\text { Safeguard \#5: } \\
\text { Enhanced Social Benefits } \\
\text { (Benefit Sharing) }\end{array}$ \\
\hline Tanzania & $\begin{array}{l}\text { Cross-sectoral discussions } \\
\text { on reconciling provisions in } \\
\text { legally-binding instruments } \\
\text { related to various } \\
\text { agreements }\end{array}$ & $\begin{array}{l}\text { Lack of } \\
\text { transparency and } \\
\text { accountability re: } \\
\text { forest related } \\
\text { crimes, and conflict } \\
\text { of interest between } \\
\text { forest officials and } \\
\text { illegal forest product } \\
\text { producers }\end{array}$ & $\begin{array}{l}\text { Forest and tree carbon tenure highly } \\
\text { contested and viewed as major obstacle to } \\
\text { successful REDD+ implementation; } \\
\text { Carbon rights a major focus at national scale } \\
\text { Land tenure related to biofuels and land grabs } \\
\text { fueling national debate on long-term land and } \\
\text { forest rights } \\
\text { CSOs skeptical about progress on land and } \\
\text { carbon rights } \\
\text { Major focus of media especially concern over } \\
\text { vague treatment of land tenure and resolving } \\
\text { conflicts between villagers, private } \\
\text { companies, and NGOs }\end{array}$ & $\begin{array}{l}\text { High level of donor engagement in focused } \\
\text { on awareness raising and capacity building } \\
\text { at local-level } \\
\text { Local NGOs (e.g., Tanzania Natural } \\
\text { Resources Forum (TFCG) working to raise } \\
\text { awareness of REDD+ safeguards } \\
\text { Media highlighted concerns about lack of } \\
\text { participation of key stakeholders including } \\
\text { NGOs, private companies and communities; } \\
\text { interviews with NGO leaders focused on need } \\
\text { for collaboration between government and } \\
\text { civil society or risk REDD+ failure }\end{array}$ & $\begin{array}{l}\text { No formal system, but likely to } \\
\text { be managed REDD+ Trust Fund } \\
\text { Government has agreed to have } \\
80 \% \text { of REDD+ payments go to } \\
\text { communities } \\
\text { Some confusion due to } \\
\text { pre-existing arrangements } \\
\text { under JFM and CBNRM } \\
\text { Benefit sharing under } \\
\text { decentralization interpreted } \\
\text { in different ways } \\
\text { Some projects linking of REDD+ } \\
\text { co-benefits with other schemes } \\
\text { (e.g., Forest Stewardship Council } \\
\text { certification) while REDD+ still } \\
\text { in nascent stages }\end{array}$ \\
\hline
\end{tabular}


The evolution of REDD+ in Brazil and Indonesia is strongly influenced by competing interests between the federal and state governments. Brazil has a highly decentralized system of forest governance, which includes granting licensing and enforcement responsibility to Amazonian states and municipalities. State and municipal councils are responsible for environment and forestry issues and assume responsibility for ensuring transparency and accountability among local government agencies that have taken on REDD+. While understaffing, lack of sustained funding, corruption, elite capture, and lack of transparency are major problems within government agencies at all scales, some Amazonian states have taken the lead on forest conservation strategies. Lessons from jurisdictional REDD+ programs at the subnational level, such as Acre's State System of Environmental Services (SISA) and early forest carbon projects including the Bolsa Floresta Program and Juma, indicate the need for alignment between federal and subnational initiatives, which is essential to guarantee their legality and efficiency, as well as potentially help promote the participation of those directly affected. Similar patterns regarding concerns about governance, and sub-national capacity to manage REDD+ were voiced in Indonesia, though the role of national government in policy setting and new initiatives directly related to REDD+ appears to be stronger. In Tanzania, there were also concerns about transparent governance. Lack of accountability for forest-related crimes, and conflicts of interest between forest officials and illegal forest product producers were identified as a major concern. Despite differences in sub-national capacity, in all three countries transparent governance was viewed as a necessary condition for successful REDD+ implementation.

We operationalize "respecting the knowledge and rights of indigenous peoples and communities" (Safeguard \#3) by considering dialogues, processes, and actions surrounding free prior and informed consent (FPIC) and land, tree and carbon tenure. FPIC refers to consent that has been granted freely, prior, and in an informed manner, has been obtained without coercion, in advance of project authorization and commencement, and that the affected parties fully understand the scope, duration, and potential impacts of the activities [34]. Discussions surrounding FPIC have taken place in various national and sub-national forums in Brazil and Indonesia. For example, as part of building consensus on REDD+ safeguards, civil society organizations in Brazil at both the national and sub-national levels have been vocal in arguing that FPIC should be carried out among traditional populations affected by REDD+ projects in their territories and adjacent lands (this process is elaborated below).

Indonesia has made considerable progress at the national and sub-national scales in developing policies and processes for addressing FPIC. The UN-REDD Programme in cooperation with National Forestry Council (DKN) developed FPIC materials and guidelines, and the recent draft of the National REDD+ Strategy includes discussion of FPIC with Pillar 5 calling for "Effective involvement of the community through implementation of FPIC, safeguards, and fair and transparent benefit sharing" [35]. Civil-society organizations have also provided critical input in various national and sub-national forums, promoting the idea that involving customary and local communities in the design, implementation and other management aspects of the national REDD + strategy is essential. Despite these advances, there is a lack of clarity regarding who will give consent and how FPIC will be operationalized. Lessons learned from FLEGT and other forest governance reform processes suggest that it is not possible to fast track FPIC, but rather that it is a slow process that requires building trust and capacity. There was no explicit mention of FPIC in the Tanzania country report or media analysis, but this does not mean that this issue is irrelevant there. 
Uncertainty of land, tree, and carbon rights was noted in all country reports as a major challenge for REDD+ implementation. Land tenure is a highly contested issue in Brazil despite the country's positive record of devolving ownership and access rights to communities and smallholders [36]. Settlement of smallholders in the Brazilian Amazon, through government-sponsored colonization or redistribution of land invaded by smallholders [37], has resulted in violent conflicts and deforestation as a way to establish property rights $[38,39]$. Such tenure insecurity translates into inequities in potential REDD benefit-sharing arrangements. For example, since inhabitants of non-designated public lands ( $\sim 24 \%$ of Brazilian Amazon) and strict protected areas $(\sim 7 \%)$ do not hold exclusive rights to land, they would likely not qualify for payments for ecosystem services [40]. That said, recent advances in linking forest tenure reform and environmental compliance through the Terra Legal Program and implementation of the Rural Environmental Registry (CAR) hold promise for REDD+ [41]. There is also currently a legal framework in place to give appropriate recognition to indigenous lands (Federal Constitution of 1988 chapter VIII). Indigenous groups occupy $22 \%$ of the Brazilian Amazon, and 77\% of indigenous lands have completed a formal process of recognition. Indigenous lands are under pressure from loggers, ranchers, and miners, but borders have been largely respected due to monitoring by the groups themselves and with legal assistance from indigenous organizations [42].

Compared to Brazil, the percentage area of the forest estate under statutory ownership and access rights for indigenous people and communities in Indonesia is relatively small [36]. With forests used historically for political and economic leverage by elites, indigenous and other forest dwelling people have been marginalized and dispossessed of their forest resources and livelihoods (various sources in [43]). Although Indonesia has had decentralized forest governance since 1999, provincial and district governments have issued licenses for agriculture and mining development in forest areas that have indiscriminately affected forest communities [44]. In the era of REDD+, there have been several national policy changes that aim to clarify forest tenure and, at least in part, lay an appropriate foundation for the implementation of REDD+. For example, Indonesia's One Map Initiative, which begun in 2010, aims to resolve longstanding overlapping land claims among ministries and departments [45]. Beginning in May 2011, implementation of the Indonesia Forest Moratorium postponed the issuance of new concession licenses in natural forests and peatlands [46]. In May 2013, a landmark decision by Indonesia's Constitutional Court laid the groundwork for acknowledging statutory ownership rights of indigenous people to a significant portion of the forest estate [47]. These major advances notwithstanding, there remain large obstacles to recognizing the rights of indigenous people and communities in Indonesia. Since the landmark Constitutional Court decision, very little progress has been made toward formalizing those rights.

Forest and carbon tenure are highly contested in Tanzania and viewed as a major obstacle to the successful implementation of REDD + . Although decentralization of forest tenure rights has been ongoing in Tanzania since the early 1990s, by 2008 only $10 \%$ of forests were owned or managed by communities [36]. Speeding up the process of legitimate decentralization is a focus of Tanzania's national REDD+ strategy [48]. Policy makers and other key stakeholders expressed concerns about the inability of the national government to define and enforce property rights resulting in some forests being treated as open access resources. Issues including biofuel development and land grabs also raise concerns about medium to long-term land and forest rights. Additionally, the issue of carbon rights is 
gaining attention in national policy dialogues, and concerns have been expressed about how the Tanzanian government will interpret existing land and forest laws which may exclude communities from realizing significant carbon benefits.

All three countries have specific national and sub-national processes aimed at increasing participation at in REDD+ (Safeguard \#4). At the national-level in Brazil, the Brazilian Forum on Climate Change, Brazilian Forum of NGOs and Social Movements, and the Climate Observatory are examples of spaces where national legislation and other relevant issues are discussed and members of civil society participate. In 2009, several civil society organizations initiated a process to develop social and environmental principles and criteria for REDD+ programs and projects in Brazil. The main objectives were to strengthen forest governance and management of natural resources by indigenous peoples and local communities, encourage public participation in the policy-making process, coordinate action among all stakeholders involved, increase information transparency, and generate respect for and awareness and recognition of the rights of indigenous peoples and local communities for their territories, lands, natural resources, and traditional livelihoods and cultures [49]. The final version of Brazil's social and environmental principles and criteria for REDD+ (i.e., safeguards framework) was developed in May 2010, addressing all comments received during the public consultation process.

At the sub-national level, participatory councils and other institutional spaces for policy dialogue between government and stakeholders exist in the Legal Amazon. For example, Acre and Mato Grosso have structured state-level forums in which stakeholders affected by REDD+ can participate, and there are also forums in other Amazonian states (e.g., Tocantins State Forum for Climate Change and Biodiversity; Amazonas State Forum for Climate Change, Biodiversity, Environmental Services and Energy; Pará State Working Group on REDD+), but most lack participation by indigenous peoples. That said, some indigenous group organizations (e.g., Coordination of the Indigenous Organizations of the Brazilian Amazon (COIAB) have a permanent seat on the executive committee of the Amazon Fund.

Indonesia has several national-level policies relevant to or directly addressing the issue of participation in REDD+. For example, Environmental Impact Assessments (AMDAL) is an important instrument for assessing community participation and involvement. Evidence of community participation is required before carbon permits are issued, although concerns about the seriousness with which community involvement is addressed were raised by the Indonesian Center for Environmental Law, which found that community participation requirements were only met by applicants with large amounts of capital. A new law in 2008 (Law No. 14/2008) on Public Access to Information could facilitate effective community participation in policy making if implemented correctly. Community participation in drafting legislation and policy is regulated by Law No. 10/2004 in "Procedures for Making Legislation" but it is normative in nature, greatly restricted, and lacking operational rules. Finally, participation is one of five pillars of National REDD + architecture (Number 4) with the stated aim of a shift in paradigm and working culture towards inclusive participation by community groups, including women and vulnerable communities, in developing policy programs and protocols [35].

Several recent national initiatives have focused on engaging civil society in the safeguards policy process including roles for civil society as members of the steering and writing committees during 
development of the draft National REDD+ Strategy, engagement in UN-REDD workshops on strengthening multi-stakeholder participation, and general consultations among civil society and customary community representatives in UN-REDD activities. At the sub-national level, civil-society has also engaged in REDD+ policy implementation. For example, the Civil Society Forum for Climate Justice held workshops in Central Kalimantan, Jambi and Aceh finding that community knowledge of and participation in REDD+ was extremely limited. Overall there is a general feeling that the level of participation by stakeholders has increased, but it remains unclear as to how much input from stakeholders is influencing actual policy development and change. Concerns were also expressed about the lack of operational rules for institutionalizing participation, and the inconsistency of legal provisions granting community participation in legislation.

Tanzania's REDD+ Readiness initiatives have involved a high level of donor engagement which has facilitated the development of a cohesive strategy regarding awareness raising and capacity building at the local-level. In addition to high levels of donor engagement, long standing local non-governmental organizations (e.g., the Tanzania Natural Resources Forum and the TFCG) have been working on awareness raising of REDD + at all levels, including specifically focusing on social and environmental safeguards. These two factors have led to a relatively high level of awareness and participation in REDD+ design at both the national and local-levels.

Countries have articulated benefit-sharing arrangements to varying degrees (Safeguard \#5). Brazil has no official proposal for benefit sharing mechanisms, though several ideas have been put forward. Nepstad et al. considered the key organizational components of sharing benefits and costs for REDD+ including developing three funds: one that compensates indigenous and traditional communities to increase the viability of forest-based livelihoods; a second that offers private landowners partial compensation of $20 \%$ of the opportunity costs of any forest reserve on their land; and a government fund that covers additional costs for monitoring, protection and management of public forests [50]. A more recent report by Brazilian organizations [51] focuses on two structural models for a national REDD+ system. One model proposes REDD+ implementation at the state level, but regulated with federal government enforcement. A second model focuses on reducing emissions from deforestation for different land use categories. Funds related to each land use would be managed within Brazil's federal system by a committee or commission comprised of civil society organizations. A major issue yet to be resolved is what share of any compensation mechanism will be related to social aspects of REDD+.

At the sub-national level in Brazil, the main form of benefit sharing is incentives for maintaining conservation practices and compensation to cover REDD+ implementation costs at the property or community-level (i.e., payments for ecoystem services) (e.g., Acre and Amazonas). Despite the lack of a clear position on benefit-sharing, most pilot REDD+ projects have a primary focus on poverty reduction mechanisms rather than meeting UNFCCC voluntary agreements for reduced deforestation. For example, the Bolsa Floresta Program in Amazonas, which has implemented compensations, incentives/rewards, and interventions at the property or community level have a strong focus on equity rather than scale of deforestation.

Benefit sharing is an explicit focus of policy dialogues and the REDD+ policy process in Indonesia, with a focus on developing legal frameworks, equity, and concerns about corruption and transparency. Led by UN-REDD facilitated consultations on institutions for MRV, RELs and a benefit sharing 
system in 2009, Indonesia is a leader with respect to benefit-sharing The current version (2012) of the National REDD+ Strategy discusses funding instrument efficiency and equity in benefit sharing, but serves only as a reference rather than providing guidance on the technical aspects of benefit sharing. Guidance for the distribution of benefits from REDD+ is provided in Ministry of Forestry Regulation Number 36/Menhun-II/2009), which stipulates that benefits should be shared amount government, communities and project developers. Under the regulation, communities get anywhere from $20 \%$ (natural forest timber concessions) to $70 \%$ (community or customary forest) of benefits associated with carbon sequestration and/or storage. However, it is not clear whether this regulation will be followed due to uncertainty about the effectiveness of Ministerial degrees vs. higher government regulation, and directives that come from the Ministry of Forestry vs. the Ministry of Finance. Civil society has expressed concerns regarding benefit sharing [52], including worries about corruption, which undermines permit processes and law enforcement, tenure, and a past history of forest-related conflict [53].

Issues of benefit sharing are not-yet formalized in Tanzania although is likely that a national REDD+ Trust Fund will be established through which the central government will receive and distribute REDD+ payments. Such a system requires high levels of transparency and accountability. Due to the strong influence of Norway, the major REDD+ donor in Tanzania on community-level benefit sharing (primarily PES schemes), and pressure from key stakeholder groups, the government has agreed to have $80 \%$ of REDD+ payments go to communities. Challenges for equitable benefit sharing include past experience with forest sector decentralization and equitable benefit sharing under PFM and JFM arrangements, linkages between benefit sharing and forest and carbon tenure security, and elite capture. Greater than $50 \%$ of REDD projects are taking place in village forest reserves that fall under community-based natural resource management (CBNRM). In those areas, benefit sharing is expected to follow CBNRM guidelines; meaning communities will receive $100 \%$ of revenues. On state lands governed under JFM the plan for benefit distribution between states and communities is not clear, in part because benefits JFM guidelines for benefit sharing have not been finalized. A major problem is that under decentralization benefit sharing agreements are often interpreted in different ways and not all communities have received a flow of benefits under existing PFM and JFM structures, raising serious questions about how REDD+ would be any different. Related to Safeguard \#3, there is a general feeling among policy makers and key stakeholders that without secure tenure rights, benefit sharing mechanisms cannot work equitably. An interesting development in Tanzania is that some REDD+ proponents have linked REDD+ co-benefits with other schemes (for example, Forest Stewardship Council certification) to ensure that benefit-sharing is institutionalized while REDD + is still in a nascent stage.

\subsection{Media Discourse on REDD+ Social Safeguards}

Social safeguards as an overarching topic played a very limited role in media discourse on REDD+ and forest-based climate mitigation in the study countries. However, various aspects of REDD+ social safeguards did receive considerable attention in one or more countries. Governance was a meta-topic in only a small share of the total number of news articles in the study countries $(5 \%-6 \%$ in both Brazil and Indonesia, and roughly $10 \%$ in Tanzania), with a focus on transparency and addressing corruption 
in the forestry sector. In Brazil, the media raised concerns about the distribution and control of resources, relations between federal and state-levels, with states struggling to improve their positions related to REDD+ financing, and whether funds should move through mechanisms such as the Amazon Fund or through carbon markets. In Indonesia, media coverage on governance focused on transparency, accountability, and coordination, with specific attention to concerns about corruption and REDD+ financial flows. The Tanzanian media focused on illegal logging and charcoal as major forest policy issues that needed to be resolved for REDD+ to be successfully implemented.

The media in Tanzania has placed considerable focus on land tenure. Several articles aired concerns about the implementation of REDD+ and how land tenure, land and carbon rights will be dealt with. Specifically, the media raised concerns about the National REDD + Strategy draft and its vague treatment of land tenure, speculating that unresolved tenure could create conflicts among villagers, private companies and NGOs as REDD+ comes into effect. Civil society organizations and local environmental NGOs used the media to express scepticism about REDD+ due to pending uses related to benefit sharing, land and carbon rights - and to convey that Tanzania's national REDD+ program should promote pro-poor, equitable environmental policy decisions. Land and carbon tenure did not feature significantly in the media analysis of REDD+ in either Brazil or Indonesia. In Brazil, media dialogue on REDD+ funding mechanisms gave minor attention to clarifying rights to forest carbon. In Indonesia, discussions on tenure were limited to land grabs and land conflicts, as well as land rights and carbon accounting in the context of giving greater control over forests to the state or carbon traders.

In the Brazilian media the topic of participation in REDD+ design received considerable attention. In 2009, newspapers discussed the role of indigenous peoples in forest conservation, particularly during a court hearing into the legality of the demarcation of the Raposa Serra do Sol Indigenous Area in Roraima State. In Indonesia, participation was addressed in the context of calls for greater participation among regional governments that have a better understanding of the potential and conditions in their regions, but the media did not focus on issues related to local participation. In Tanzania, concerns were expressed in the media that the National REDD+ Strategy draft failed to consider non-governmental organizations, private companies and communities as ad hoc participants giving them no core decision making functions. Media interviews with leaders of national and international conservation NGOs emphasized the need for good collaboration between government and civil society, or risk the failure of REDD+ if local people and civil society groups were not given adequate voice.

Benefit-sharing also got limited attention. Other than broad discussions of equity and REDD+, benefit-sharing was not a dominant theme in the Brazilian media. Attention was given to the issue of opportunity costs and the realization that to keep forests standing forest owners need to be financially compensated. In the Indonesian media, discourse on the distribution of REDD + costs and benefits with concerns that costs will be borne by one group of actors (local and indigenous communities) and benefits will be appropriated by more powerful groups (capitalist elites and opportunistic carbon brokers) were expressed, including statements that REDD+ might support "environmental racism" by undermining community dependence on conservation areas. At the sub-national level, bureaucrats, domestic businesses and international NGOs expressed concern with issues of equity in REDD+ pilots 
as mechanisms, but also a willingness to support implementation as long as it benefits local forest dwelling communities.

Many of the newspaper articles in Tanzania were related to forest conservation as a means of earning income, emphasizing the role of local farmers and communities as forest owners and users who were not compensated under various past sustainable forest management initiatives. The media articulated that forest users should receive compensation for their efforts in conserving forests under REDD+, but also acknowledged that forest officials do not have capacity to monitor forest use to the extent that is required for REDD+. However, REDD+ was also viewed as a mechanism for directing cash flow/compensation to forest managers and owners facilitating capacity building for forest governance. REDD+ advocates quoted in the Tanzanian media focused on ensuring joint benefits of reduced deforestation and enhancing community livelihoods. Recent media coverage (2012) focused on announcements from the international conservation community that communities who are responsible for protecting forests should receive the bulk of REDD+ payments.

\subsection{Processes and Actions Related to REDD+ Safeguards in Subnational REDD+ Initiatives}

Though still in their early stages, many subnational REDD+ initiatives included in GCS-REDD+ have incorporated elements of the UNFCCC safeguards into their implementation plans. All but four reported having obtained or plan to obtain CCB or REDD+ SES certification. These standards require initiatives to obtain FPIC from all local communities (indigenous or otherwise). When asked about obtaining FPIC, most teams had obtained or planned to obtain FPIC (in 50 out of 59 villages in the GCS-REDD+ sample). Nine initiatives provided information about the type of consent obtained (or planned for), with most securing consent through oral agreement and only two by written permission. Five of the nine had consulted with sub-groups as part of the FPIC process.

The scale of the initiative appears to affect the attention paid to FPIC, in particular the definition of the person or group giving consent and the distribution of information about the initiative. Teams from the larger jurisdictional initiatives, some of which involved entire states and provinces or multiple administrative districts or municipalities, sought to obtain agreement from state- and district-level administration, as well as government agencies, communities and industry sectors. The smaller-scale initiatives (sub-district or municipality) primarily sought agreement from village-level institutions or from the community itself via community meetings. One project hired lawyers for the community and encouraged them to seek independent advice before committing. The larger initiatives tended to inform communities through stakeholder workshops, while the smaller ones used local media (primarily radio), as well as distributing posters and leaflets and holding question and answer sessions.

Proponents' motivations for conducting FPIC fall into three categories: (i) upholding human rights; (ii) complying with such formal rules or institutions as voluntary standards (e.g., CCB) or national law (e.g., Tanzania Land Act); and (iii) achieving reductions in deforestation and degradation. Achieving overall project effectiveness (which might be defined exclusively by forest carbon goals or joint environmental-social goals) and upholding human rights are the primary motivations. In line with the emphasis on rights and effectiveness, some proponents stated that obtaining FPIC could never be complete, since FPIC is "a process and not an event" and "by definition it never ends". Although there are strong motivations for conducting FPIC in REDD+, there are also factors that induce some 
proponents to delay fully informing local stakeholders about REDD+. At six of the GCS sites (three in Brazil and three in Indonesia), proponents decided to delay mentioning the term "REDD+" and fully explaining their programmatic intentions [54]. With uncertainty about the future funding stream for REDD+, some proponents were reluctant to conduct outreach about REDD+ to avoid unnecessarily raising the expectations of local stakeholders.

Proponents also noted that the information disclosure requirements and transaction costs associated with FPIC can cause problems. Staff had difficulty in getting a sufficient proportion of people to attend information meetings. They also found it a challenge to secure sufficient financial and time resources for the participation process; especially in ensuring that information about the initiative reached individual households in a timely manner. One proponent noted that, despite having signed agreements and building a good level of trust, "FPIC is an impossible dream" and "actually very difficult to deliver". The incipient nature of REDD+ poses a further challenge, since FPIC asks people to consent to something that is still evolving and has a number of open questions regarding compensation for changing land use.

Most proponents of subnational initiatives involved local communities in program or project design and implementation, for example, in identifying the drivers of deforestation and degradation, developing baseline scenarios, and deciding on appropriate intervention and alternative livelihood activities. In one initiative, local communities helped shape the wording of contracts. Stakeholder meetings organised by the Government of Acre in Brazil led to a fundamental overhaul of the design of the State System of Incentives for Environmental Services, replacing an earlier program focused on priority areas with a more comprehensive state-wide programme and shifting the emphasis from payments to incentives for environmental services. The main challenges proponents faced with respect to participation were: identifying leaders who truly represent the community/sector; ensuring local communities have a meaningful voice in decision making; and the financial resources needed to enable full participation, especially when attempting to reach migrant or nomadic populations.

\section{Discussion}

We have analysed what multi-level dialogues, processes, and actions on core aspects of REDD+ social safeguards mean for the development of national-level safeguards systems. While Brazil, Indonesia and Tanzania all have flagship REDD+ programs, they differ in important ways that influence the speed and depth of development of safeguard policies, and in their ability to measure, report and verify adherence to social safeguards. Importantly, none of the countries included in our analysis have cleanly nested structures that lend themselves to the easy aggregation of social safeguard indicators. Our analysis highlights the polycentric nature of dialogues, processes and actions related to social safeguards in all three countries, suggesting challenges for measuring, reporting and verifying compliance, but also opportunities with respect to transparency and triangulation of information.

Brazil has arguably advanced further than any other country with respect to national policy dialogues on social safeguards. After several consultative processes involving a wide range of stakeholder groups, the Ministry of Environment (MMA) organized two meetings in 2011 including representatives of different sectors of civil society and government. The meetings were held as part of the development of the Brazilian REDD+ national strategy with the objective of evaluating whether 
the proposed safeguard framework adequately covers the main risks to biodiversity and indigenous peoples/local communities. After reviewing different approaches and definitions of safeguards including those put forward by international and national stakeholders including the FCPF, UN-REDD, CCBA, Brazilian Principles and Criteria for REDD+, and a document developed by the National Agency for Indigenous People (FUNAI) on REDD+ implementation on indigenous lands, MMA presented a list of nine safeguards for consideration for Brazil's REDD+ national strategy: legal regulation, guarantee of rights, economic sustainability and poverty reduction, biodiversity conservation and recovery, governance, benefit-sharing, monitoring and transparency, permanence and leakage, and participation. These principles and criteria are now serving as basis for the development of Brazil's national REDD+ strategy and SIS.

In Brazil, there have also been important advances at the subnational level in terms of safeguards implementation. The states of Acre, Amazonas and Mato Grosso are involved in the REDD+ SES Initiative to develop subnational SIS. Acre, as a pilot in the initiative, is the most advanced of the three having set up an innovative state commission for safeguard validation and monitoring within its System of Incentives for Environmental Services. Acre prepared its monitoring and assessment plan, and is currently collecting and assessing monitoring information. Amazonas and Mato Grosso entered into the initiative more recently, and are at the early stage of building capacity among stakeholders and establishing facilitation teams.

Despite Brazil's advances, our analysis highlights several challenges that must be addressed in working towards compliance with social safeguards. First, there is a need to better integrate the powerful business-as-usual interests that go directly against REDD+ to promote synergies in national policy. Second, there is a need for harmonization of safeguard policies at subnational and national levels. Third, advances in linking land tenure reform with environmental compliance should continue to secure local rights to land and resources. Finally, there is need for clarity on what share of compensation mechanisms will be related to social aspects of REDD+ in a national benefit sharing agreement.

The establishment of clear policy for implementing national-level social safeguards for REDD+ lags behind in Indonesia insofar as there is no explicit strategy for operationalizing REDD+ safeguards. A major focus of much of the discussion surrounding REDD + safeguards in Indonesia has been the right of communities to FPIC, including withholding consent. In 2011, several initiatives were launched to bring together stakeholder groups to discuss key aspects of social safeguards. For example, the National Forestry Council, a multi-stakeholder advisory body to the National Ministry of Forestry, released recommendations on FPIC and REDD+ after several months of consultation with a wide range of stakeholders including representatives from indigenous groups.

Strategy documents recognize several key elements of REDD + social safeguards. Indonesia's National REDD+ Strategy [35] explicitly addresses the issue of governance focusing on coordination among government departments and agencies and issues related to enforcement. The importance of both national and sub-national stakeholder engagement and participation including outlining the need for FPIC and ongoing consultation with stakeholders, the role of land rights and tenure including recognizing problems associated with land conflicts, unclear forest ownership status and boundaries, lack of formal rights and alternative livelihood strategies for indigenous peoples, and discusses co-benefits and the need for a benefit distribution system were also discussed. 
At the subnational level, two Indonesian provinces are part of the REDD+ SES Initiative (Central and East Kalimantan). As a pilot in the initiative, Central Kalimantan has advanced considerably with SIS development and is at the stage of collecting and assessing monitoring information. The provincial government of Central Kalimantan is supported by the Indonesian Ecolabelling Institute in this initiative. East Kalimantan is forming a standards committee and drafting province-specific indicators.

For Indonesia to move forward several barriers need to be addressed. Similar to Brazil, there is a need for synergy between REDD + policy and agricultural and industrial policies that go against REDD+. There is also a need to link provincial-level advances in safeguard policy development with national-level processes. Finally, social safeguards in Indonesia must move beyond discussions on FPIC to promote and operationalize community participation in REDD + design and implementation and equitable benefit-sharing mechanisms.

The safeguard process in Tanzania also lags quite far behind that of Brazil, and is quite different from both Brazil and Indonesia, in part because Tanzania does not have strong sub-national leadership as seen in the other two countries. This means that all decisions and advances on safeguard related issues are taken at the national-scale, with limited input and/or innovation from the regions. Secondly, the presence of indigenous peoples as an organized group does not play a large role in deliberations and processes surrounding safeguards. This is quite different than the core of much of the safeguards dialogue in Brazil and Indonesia. That said, Tanzania has fully participated in a number of international initiatives related to safeguards frameworks including being part of the UN-REDD and the FCPF programs, and serving as a pilot for REDD+ SES. However, a second draft of the National REDD+ Strategy gives no indication of which set of guidelines or standards will be used for the development of safeguards, but states that existing legal frameworks, such as the Environmental Policy Act of 1997 and the Environmental Management Act of 2004, will be used as benchmarks for integrating environmental and social impact assessment into policy and decision making processes for REDD+ and related sectors.

Our results highlight distinct challenges for advancement of social safeguards in Tanzania. The government's slow recognition of tenure rights, along with the new question of carbon rights, present major obstacles to REDD+ implementation. There seems to be genuine concerns from many stakeholders with a wide array of governance issues and the way in which participation is being promoted. Finally, similar to the other countries, there is a need for a clear benefit sharing mechanism that builds from existing arrangements, in this case under JFM and PFM.

\section{Conclusions}

REDD + safeguards are evolving in multiple policy arenas, and being applied at different scales of governance from local to international. These multiple systems are not nested (i.e., vertically integrated), but are instead overlapping or polycentric, which presents both challenges and opportunities. The debate over whether and how to take specific steps to safeguard human welfare in REDD+ has generated a plethora of policy and media discourse, as well as concrete progress at national and sub-national levels. Our analysis in three countries most advanced in the development of their REDD+ programs suggests variable progress towards building national REDD+ safeguard MRV 
systems. Brazil is by far the most advanced having drafted a REDD+ social safeguards policy. Both Brazil and Indonesia have benefited from progress made by strong sub-national entities in the operationalization of REDD+ safeguards including FPIC, participation, and benefit sharing. Tanzania has weakly articulated how social safeguards will be operationalized and has a much more top-down approach. All three countries share the challenge of decentralized systems that have underperformed, numerous governance related issues (e.g., corruption and lack of accountability), and deep concerns about how or if land, tree, and carbon tenure reform will take place.

As for Brazil, Indonesia and Tanzania, measuring, reporting and verifying progress on social safeguards is likely to be a complex issue in most settings. At present, most REDD+ countries are grappling with the minimum requirements of demonstrating reduced deforestation and degradation. If they can achieve capacity in carbon MRV, which encompasses leakage and permanence, those two safeguards can be effectively and regularly monitored. However, national-level assessment of social impacts and biodiversity co-benefits is a significant challenge, which has thus far received limited attention in most REDD+ countries. As countries begin to implement SIS, there is a need for greater international guidance on the use of appropriate indicators, data collection methods, and reporting frameworks. While this lack of guidance supports national ownership, it also creates uncertainties and high transaction costs. The process is complicated by a lack of harmonization among the various safeguard policies and disconnects between REDD+ monitoring efforts at different scales. For instance, it is still unclear how subnational jurisdictions' advancement with SIS will dovetail with national-level efforts. Limitations in capacity to implement, monitor and enforce REDD+ safeguards are critical issues in need of attention. Much of the safeguards' discourse has been overly focused on what safeguards should be, but now countries are faced with operationalizing them in a meaningful way. We flag the tension between national reporting on social safeguards and providing high quality and timely data that reflect the ground realities. This tension speaks for the need for community monitoring and participatory processes that feed into national-scale assessments of REDD+ social impacts and benefit sharing. We point to Danielsen et al. [55] who make a strong case for community monitoring of carbon stocks, but caution that evaluation of social impacts may be open to greater subjectivity and less transparent verification than for carbon. Another key challenge for social safeguards is the low funding for REDD + in general. Incentives for REDD+ are currently high because irrespective of funding, climate change mitigation can serve national interests. However, without a major new injection of funding in the near future, there are clear risks that interest in REDD + and relatedly, social safeguards, will wane.

\section{Acknowledgments}

This paper has been produced with the financial assistance of the Norwegian Agency for Development Cooperation (Norad), the Australian Department of Foreign Affairs and Trade, the Department for International Development (DFID) of the United Kingdom, the European Commission (EC), the CGIAR Research Program on Forests, Trees and Agroforestry (CRP-FTA), and funding partners who have contributed to the CGIAR Fund. We are grateful to the GCS-REDD+ country-level research teams for outstanding collaboration. We also acknowledge the REDD+ proponents, community leaders, and other key informants who responded to our questions. The opinions expressed 
are those of the authors and do not necessarily represent the views of CIFOR, the authors' institutions or the funding partners.

\section{Author Contributions}

Pamela Jagger contributed to the research design for GCS-REDD+. Maria Brockhaus leads the module of GCS-REDD+ responsible for the country-level policy and media analysis. Amy Duchelle coordinates GCS-REDD+ research activities in Latin America. Maria Fernanda Gebara was involved in data collection in Brazil. Kathleen Lawlor analyzed the initiative-level data. Ida Aju Pradnja Resosudarmo coordinates GCS REDD+ research activities in Indonesia. William D. Sunderlin leads the module of GCS-REDD+ on REDD+ subnational initiatives. Pamela Jagger, Amy E. Duchelle, Maria Fernanda Gebara, and Kathleen Lawlor conducted the comparative analysis and wrote the paper.

\section{Conflicts of Interest}

The authors declare no conflict of interest.

\section{References}

1. Kshatriya, M.; Sills, E.O.; Lin, L. Global Database of REDD+ and other Forest Carbon Projects. Interactive Map. Available online: http://www.forestsclimatechange.org/redd-map/ (accessed on 20 September 2012).

2. Angelsen, A.; Atmadja, S. What is this book about? In Moving Ahead with REDD: Issues, Options and Implications; Angelsen, A., Ed.; CIFOR: Bogor, Indonesia, 2008; pp. 1-10.

3. Lawlor, K.; Olander, L.P.; Weinthal, E. Sustaining Livelihoods While Reducing Emissions From Deforestation: Options for Policymakers; Nicholas Institute for Environmental Policy Solutions Working Paper 09-02; Duke University: Durham, NC, USA, 2009.

4. Brown, D.; Seymour, F.; Peskett, L. How Do We Achieve REDD Co-benefits and Avoid Doing Harm? In Moving Ahead with REDD: Issues, Options and Implications; Angelsen, A., Ed.; CIFOR: Bogor, Indonesia, 2008; pp. 107-118.

5. Ostrom, V.; Tiebout, C.M.; Warren, R. The Organization of Government in Metropolitan Areas: A Theoretical Inquiry. Am. Polit. Sci. Rev. 1961, 55, 831-842.

6. Ostrom, E. Understanding Institutional Diversity; Princeton University Press: Princeton, NJ, USA, 2005.

7. Luttrell, C.; Loft, L.; Gebera, M.F.; Kweka, D.; Brockhaus, M.; Angelsen, A.; Sunderlin, W.D. Who Should Benefit from REDD+? Rationales and Realities. Ecol. Soc. 2013, 18, 52.

8. Kweka, D. The Context of REDD + in Tanzania: Drivers, Agents and Institutions; CIFOR: Bogor, Indonesia, 2012.

9. Indrarto, G.B.; Muharjanti, P.; Khatarina, J.; Pulungan, I.; Ivalerina, F.; Rahman, J.; Prana, M.N.; Resosudarmo, I.A.P.; Muharrom, E. The Context of REDD+ in Indonesia: Drivers, Agents, and Institutions; CIFOR Working Paper 92; CIFOR: Bogor, Indonesia, 2012.

10. May, P.H.; Millikan, B.; Gebara, M.F. The Context of REDD+ in Brazil: Drivers, Agents, and Institutions; CIFOR Occasional Paper 55; CIFOR: Bogor, Indonesia, 2011. 
11. May, P.; Calixto, B.; Gebara, M.F. REDD+ Politics in the Media: A Case Study from Brazil; CIFOR Working Paper 55; CIFOR: Bogor, Indonesia, 2011.

12. Cronin, T.; Santoso, L. REDD+ Politics in the Media: A Case Study from Indonesia; CIFOR Working Paper 49; CIFOR: Bogor, Indonesia, 2010.

13. Kweka, D. REDD+ Politics in the Media: A Case Study from Tanzania; CIFOR Working Paper 119; CIFOR: Bogor, Indonesia, 2013.

14. Caplow, S.; Jagger, P.; Lawlor, K.; Sills, E. Evaluating Land Use and Livelihood Impacts of Early Forest Carbon Projects: Lessons for Learning about REDD+. Environ. Sci. Policy 2011, 14, 152-167.

15. United Nations Framework Convention on Climate Change (UNFCCC). Addendum: Part Two: Action Taken by the Conference of the Parties at its Thirteenth session, FCCC/CP/2007/6/Add.1. In Proceedings of the Conference of the Parties on its Thirteenth Session, Bali, Indonesia, 3-15 December 2007; UNFCCC: Bali, Indonesia, 2008.

16. Lawlor, K.; Huberman, D. Reduced emissions from deforestation and degradation (REDD) and human rights. In Rights-based Approaches: Exploring Issues and Opportunities for Conservation; Campese, J., Sunderland, T., Greiber, T., Oviedo, G., Eds.; CIFOR and IUCN: Bogor, Indonesia, 2009; pp. 269-286.

17. Brandon, K.; Wells, M. Lessons for REDD+ from protected areas and integrated conservation and development projects. In Realising REDD+: National Strategy and Policy Options; Angelsen, A., Brockhaus, M., Kanninen, M., Wertz-Kannounikoff, S., Sills, E., Sunderlin, W., Eds.; CIFOR: Bogor, Indonesia, 2009; pp. 225-235.

18. United Nations Framework Convention on Climate Change (UNFCCC). The Cancun Agreements: Outcome of the Work of the Ad Hoc Working Group on Long-term Cooperation Under the Convention, Decision 1/CP.16, FCC/CP/2010/7 Add.1. In Proceedings of the Conference of the Parties on its Sixteenth Session, Cancun, Mexico, 29 November-10 December 2010; UNFCCC: Bonn, Germany, 2011.

19. United Nations Framework Convention on Climate Change (UNFCCC). Decision on Guidance on Systems for Providing Information on How Safeguards are Addressed and Respected and Modalities Relating to Forest Reference Emission Levels and Forest Reference Levels as Referred to in Decision 1/CP.16, Decision 12/CP.17; In Proceedings of the Conference of the Parties on its Seventeenth Session, Durban, South African, 28 November-11 December 2011; UNFCCC: Bonn, Germany, 2012.

20. Ad-hoc Working Group on Long-Term Cooperative Action (AWG-LCA). Work of the AWG-LCA: Informal Overview Note by the Chair; AWG-LCA: Bangkok, Thailand, 2012.

21. United Nations Framework Convention on Climate Change (UNFCCC). Outcome of the Work of the Ad Hoc Working Group on Long-term Cooperative Action under the Convention, FCCC/AWGLCA/2012/L.4. In Proceedings of the Ad Hoc Working Group on Long-term Cooperative Action under the Convention on the Second Part of Its Fifteenth Session, Doha, Qatar, 27 November-7 December 2012; UNFCCC: Bonn, Germany, 2012. 
22. United Nations Framework Convention on Climate Change (UNFCCC). Decision 9/CP.19: Work Programme. on Results-based Finance to Progress the Full Implementation of the Activities Referred to in Decision 1/CP.16, paragraph 70. In Proceedings of the Conference of the Parties on its nineteenth session, Warsaw, Poland, 11-23 November 2013; UNFCCC: Bonn, Germany, 2014.

23. EcoSecurities. Forest Carbon Offset Reporting 2010; EcoSecurities Group: Dublin, Ireland, 2010.

24. Diaz, D.; Hamilton, K.; Johnson, E. State of the Forest Carbon Markets 2011: From Canopy to Currency; Forest Trends: Washington, DC, USA, 2011.

25. Cashore, B. Legitimacy and the Privatization of Environmental Governance: How Non-state Market-driven (NSMD) Governance Systems Gain Rule-making Authority. Governance 2002, 15, 503-529.

26. REDD+ SES. The REDD + Social and Environmental Standards. Version 2. REDD+ Social and Environmental Standards Initiative: Washington DC, USA, 2013. Available Online: http://www.redd-standards.org/ (accessed on 4 April 2013).

27. Rapp, K.W. World Bank Safeguards as the Basis for Environmental and Social Risk Management for the Forest Carbon Partnership Facility (FCPF). In Proceedings of the SBSTA Expert Meeting on "Guidance on systems for providing information on how safeguards for REDD+ activities are addressed and respected", Panama City, Panama, 8-9 October 2011. Available Online: http://unfccc.int/files/methods_science/redd/application/pdf/fcpf_sesa+esmf_presentation_8oct20 11.pdf (accessed on 23 September 2012).

28. UN REDD. UN-REDD Programme. Social and Environmental Principles and Criteria; The United Nations Programme on Reducing Emissions from Deforestation and Forest Degradation in Developing Countries: Geneva, Switzerland, 2012. Available online: http://www. un-redd.org/multiple_benefits_sepc/tabid/54130/default.aspx (accessed on 14 October 2012).

29. Movius, D.; Elias, P.; Davis, S.; Ogonowski, M. Application of International REDD Agreements to California's REDD Offset Program: A Three Phase Approach Applied to Subnational REDD Strategies and $A B$ 32; Center for Clean Air Policy: Washington, DC, USA, 2012. Available online: http://www.ccap.org/docs/resources/1089/California\%20REDD\%20phases\%20and\%20 offsets\%20CCAP\%20March\%202012\%20FINAL.pdf (accessed on 11 May 2012).

30. Hite, K. Safeguards and REDD, 2012. Rights Resources. Available online: http://www. rightsandresources.org/documents/files/doc_1513.pdf (accesed on 22 April 2012).

31. GCS. CIFOR's Global Comparative Study on REDD+: Factsheets on Research Findings and Goals; CIFOR: Bogor, Indonesia. Available online: http:/www.cifor.org/publications/pdf_files/ factsheet/4259-factsheet.pdf (accessed on 4 April 2013).

32. Boykoff, M.T. The Cultural Politics of Climate Change Discourse in UK Tabloids. Polit. Geogr. 2008, 27, 549-569.

33. Di Gregorio, M.; Price, S.; Saunders, C.; Brockhaus, M. Code Book for the Analysis of Media Frames in Articles on REDD; CIFOR: Bogor, Indonesia, 2012.

34. Anderson, P. Free, Prior, and Informed Consent in REDD+: Principles and Approaches for Policy and Project Development; RECOFTC and GTZ: Bangkok, Thailand, 2011.

35. Indonesian REDD + Task Force. REDD + National Strategy; Indonesian REDD+ Task Force: Jakarta, Indonesia, 2012. 
36. Sunderlin, W.D.; Hatcher, J.; Liddle, M. From Exclusion to Ownership? Challenges and Opportunities in Advancing Forest Tenure Reform; Rights and Resources Initiative: Washington, DC, USA, 2008.

37. Pacheco, P. Agrarian reform in the Brazilian Amazon: Its Implications for Land Distribution and Deforestation. World Dev. 2009, 37, 1337-1347.

38. Alston, L.J.; Libecap, G.D.; Mueller, B. Land Reform Policies, the Sources of Violent Conflict, and Implications for Deforestation in the Brazilian Amazon. J. Environ. Econ. Manag. 2000, 39, $162-188$.

39. Aldrich, S.; Walker, R.; Simmons, C.; Caldas, M.; Perz, S. Contentious Land Change in the Amazon's Arc of Deforestation. Ann. Assoc. Am. Geogr. 2012, 102, 103-128.

40. Börner, J.; Wunder, S.; Wertz-Kanounnikoff, S.; Tito, M.R.; Pereira, L.; Nascimento, N. Direct Conservation Payments in the Brazilian Amazon: Scope and Equity Implications. Ecol. Econ. 2010, 69, 1272-1282.

41. Duchelle, A.E.; Cromberg, M.; Gebara, M.F.; Guerra, R.; Melo, T.; Larson, A.; Cronkleton, P.; Börner, J.; Sills, E.O.; Wunder, S.; et al. Linking Forest Tenure Reform, Environmental Compliance, and Incentives: Lessons from REDD+ Initiatives in the Brazilian Amazon. World Dev. 2014, 55, 53-67.

42. Nepstad, D.; Schwartzman, S.; Bamberger, B.; Santilli, M.; Ray, D.; Schlesinger, P.; Lefebvre, P.; Alencar, A.; Prinz, E.; Fiske, G.; et al. Inhibition of Amazon Deforestation and Fire by Parks and Indigenous Lands. Conserv. Biol. 2006, 20, 65-73.

43. Resosudarmo, I.A.P.; Atmadja, S.; Ekaputri, A.D.; Intarini, D.Y.; Indriatmoko, Y.; Astri, P. Does Tenure Security Lead to REDD+ Project Effectiveness? Reflections from Five Emerging Sites in Indonesia. World Dev. 2014, 55, 68-83.

44. Resosudarmo, I.A.P. Has Indonesia's Decentralization Led to Improved Forestry Governance? A Case Study of Bulungan and Kutai. Barat districts, East Kalimantan; Ph.D. Thesis, Australian National University: Canberra, Australia, 2007.

45. Samadhi, N. Indonesia ONE MAP: Assuring Better Delivery of National Development Goals; Geospatial World Forum: Rotterdam, The Netherlands, 2013. Available online: http://www.geospatialworldforum.org/2013/presentation/Nirata\%20Samdhi.pdf (accessed on 2 May 2013).

46. Murdiyarso, D.; Dewi, S.; Lawrence, D.; Seymour, F. Indonesia's Forest Moratorium: Stepping-Stone to Better Forest Governance? CIFOR Working Paper 76; CIFOR: Bogor, Indonesia, 2011.

47. Kahurani, E. Indonesia upholds Indigenous People's Rights to Forest. Alternatives to Slash and Burn; ASB Partnership for the Tropical Forest Margins: Nairobi, Kenya, 2013. Available online: http://www.asb.cgiar.org/story/category/indonesia-upholds-indigenous-people $\%$ E2\%80\%99srights-forest\#sthash.EliRgtoE.dpuf (accessed on 3 May 2013).

48. Dokken, T.; Caplow, S.; Angelsen, A.; Sunderlin, W.D. Tenure Issues in REDD+ Pilot Project Sites in Tanzania. Forests 2014, 5, 234-255.

49. Gomes, R.; Bone, S.; Cunha, M.; Nahur, A.C.; Moreira, P.F.; Meneses-Filho, L.C.L.; Voivodic, M.; Bonfante, T.; Moutinho, P. Exploring the Bottom-up Generation of REDD+ Policy by Forest-dependent Peoples. Policy Matters 2010, 17, 161-168. 
50. Nepstad, D.B.; Soares-Filho, B.; Merry, F.; Moutinho, P.; Rodrigues, A.; Schwartzman, S.; Almeida, O.; Rivero, S. Reducing Emissions from Deforestation and Forest Degradation (REDD): The Costs and Benefits of Reducing Carbon Emissions from Deforestation and Forest Degradation in the Brazilian Amazon; Woods Hole Research Center: Falmouth, MA, USA, 2007.

51. CGEE, IPAM, SAE. REDD no Brasil: Um Enfoque Amazônico: Fundamentos, Critérios e Estruturas Institucionais para um Regime Nacional de Redução de Emissões por Desmatamento e Degradação Florestal-REDD; Centro de Gestão e Estudos Estratégicos: Brasília, Brazil, 2011.

52. CSF. REDD, Bisakah Menjawab Deforestasi dan Menghadirkan Keadilan Iklim? Pembelajaran dari Indonesia; Civil Society Forum for Climate Justice: Jakarta, Indonesia, 2010.

53. Yasmi, Y.; Kelly, L.; Murdiyarso, D.; Patel, T. The Struggle over Asia's Forests: An Overview of Forest Conflict and Potential Implications for REDD+. Int. For. Rev. 2012, 14, 99-109.

54. Sunderlin, W.D.; Larson, A.M.; Duchelle, A.E.; Resosudarmo, I.A.P.; Huynh, T.B.; Awono, A.; Dokken, T. How are REDD+ Proponents Addressing Tenure Problems? Evidence from Brazil, Cameroon, Tanzania, Indonesia, and Vietnam. World Dev. 2014, 55, 37-52.

55. Danielsen, F.; Adrian, T.; Brofldt, S.; van Noordwijk, M.; Poulsen, M.K.; Rayayu, S.; Rutishauser, E.; Theilade, I.; Widayati, A.; Burgess, N. Community Monitoring for REDD+: International Promises and Field Realities. Ecol. Soc. 2013, 18, 41.

(C) 2014 by the authors; licensee MDPI, Basel, Switzerland. This article is an open access article distributed under the terms and conditions of the Creative Commons Attribution license (http://creativecommons.org/licenses/by/3.0/). 